\title{
A APLICAÇÃO DAS MÁXIMAS DE EXPERIÊNCIAS NO PROCESSO CIVIL DE CONHECIMENTO
}

FRANCISCO ROSITO

Data da defesa: $21 / 12 / 2004$

\section{RESUMO}

O presente trabalho objetivou analisar a aplicação das máximas de experiência no processo civil de conhecimento. Inicialmente foram abordados os pressupostos dogmáticos da categoria, sobretudo a valoração da prova e o convencimento judicial. Uma vez assentadas as premissas metodológicas, examinou-se o perfil dogmático da categoria. Foram apresentados os seus antecedentes históricos, as suas características, até as diferenças entre as máximas de experiência e determinadas categorias afins. Abordou-se posteriormente o tratamento probatóio a respeito do tema. Por serem regras gerais procedentes da experiência comum ou técnica, as máximas de experiência não dependem de prova. A exceção ocorre quando se tratar de regta técnica ou científica que não seja do domínio da cultura média, o que desqualifica a própria condição de máximá. Focaram-se também as funções exercidas pela categoria. As máximas de experiência podem funcionar para avaliar a credibilidade das provas direta $e$ indireta e para interpretar a prova colhida, a fim de que seja formado o convencimento judicial acerca da questão fática. $\mathrm{Na}$ prova indireta, desempenham ainda uma função instrumental específica, constituindo o meio ou o instrumento necessário para que o juiz possa chegar ao fato desconhecido, a partir de inferências sobre o dado probatório. Na prova "prima facie", servem de fundamento à sua aplicação, representando aquilo que ordinatiamente acontece. As máximas de experiência podem, outrossim, atuar na interpretação das normas jurídicas, ao fornecerem material semânicico e standards de individuação das acepções dos enunciados nomativos, quer da linguagem comum, quer da linguagem jurídica, tomando inteligiveis essas expressões. Além disto, desempenham papel importante na determinação do suporte fático de cláusulas getais ou conceitos jurídicos indeterminados, cada vez que reclamem um preceito da experiência ordinária ou da experiência técnica à sua incidência. Ao ser examinada a funcionalidade da categoria, foi analisado o controle possivel a que poden ser submetidas as máximas de experiência, para que os destinatárjos das decisões tenham condições de compreender e controlar o iter lógico seguido pelos julgadores, com base em critétios racionais. Por fim, foi analisado o tratamento conferido pelos tribunais brasileitos às máximas de experiência nas suas diversas funções. Palavras-chave: Direito Processual Civil - Processo de Conhecimento - Juiz (Direito)

5 Sob a orientação do Professor Doutor Carlos Alberto Alvaro de Oliveira, Professor Titular da Universidade Federal do Rio Grande do Sul, Doutor em Direito pela Universidade de São Paulo, contando com a participação do Professor Doutor Flávio Luiz Yarshell, Professor da Universidade de São Paulo, e Doutor em Direito pela Universidade de São Paulo; pelo Professor Doutor Adroaldo Furtado Fabrício, Professor Titular de Direito Processual Civil e Livre Docente da Universidade Federal do Rio Grande do Sul, Doutor em Processo Civil pela Universidade Fedetal do Rio Grande do Sul e pelo Professor Doutor Darilo Knijinik, Professor da Universidade Federal do Rio Grande do Sul, e Doutor em Direito pela Universidade de São Paulo. A referida defesa foi presidida pelo Professor Doutor Carlos Alberto Alvaro de Oliveira. 